\title{
Expression of mRNA for follicle-stimulating hormone suppressing protein in ovarian tissues of cows
}

\author{
L. Shukovski, Z. W. Zhang, U. Michel and J. K. Findlay \\ Prince Henry's Institute of Medical Research, PO Box 118, South Melbourne, 3205, Victoria, \\ Australia
}

\begin{abstract}
Summary. The expression of bovine follicle-stimulating hormone (FSH)-suppressing protein (FSP) mRNA was investigated in different ovarian tissues of cows. Northern blot analysis, using a cDNA probe to bovine FSP, demonstrated that the FSP gene in the bovine ovary is highly expressed in a pool of isolated granulosa cells. Two bands $(2.8$ and $1.8 \mathrm{~kb})$ were observed in all tissues expressing the mRNA. FSP mRNA was low in small antral follicles and increased in growing follicles to reach a maximum in preovulatory follicles. Low amounts of mRNA of steady state FSP were observed in all stages of the corpus luteum as well as in the corpus luteum of pregnant cows, in the corpus albicans and theca tissue, whereas this mRNA could not be detected in the liver. These results are consistent with the hypothesis that, in cows, FSP functions as an autocrine regulator in developing follicles to facilitate luteinization of granulosa cells.
\end{abstract}

Keywords: FSH-suppressing protein; mRNA; follicle; granulosa cells; corpus luteum; cow

\section{Introduction}

Inhibin-free side fractions that contained FSH-suppressing activity were observed during the isolation and purification of inhibin (Ying, 1988). This activity was later purified and named follistatin (porcine) (Ueno et al., 1987) or FSH-suppressing protein (FSP) (bovine) (Robertson et al., 1987). FSP was shown to be biologically similar but structurally unrelated to inhibin. Northern analyses indicated that a single band of FSP mRNA $(2 \cdot 4-2 \cdot 6 \mathrm{~kb})$ was detected in the rat (Shimasaki et al., 1989), pig (Shimasaki et al., 1988a) and human (Shimasaki et al., 1988b) ovary, and also in the kidney, brain cortex (Shimasaki et al., 1989) and decidua (Kaiser et al., 1990) of adult rats, and human (Shimasaki et al., 1988b) but not rat testes. Rat decidua also expressed a $1.5 \mathrm{~kb}$ band of FSP mRNA (Kaiser et al., 1990). An $\mathbf{S}_{1}$ nuclease protection assay for FSP was used and FSP mRNA was found in a wide range of tissues of adult rats (Michel et al., 1990).

The cellular origin of the FSP mRNA and FSP is known for a few of these tissues. In the rat ovary, in situ hybridization detected FSP mRNA in granulosa cells of growing preantral and early antral follicles with lower concentrations in mature preovulatory follicles and very low concentrations in granulosa cells of primordial follicles (Shimasaki et al., 1989). Some corpora lutea showed hybridization, whereas theca, stroma and ovarian interstitial cells did not hybridize with the probe. Immunoreactive FSP is produced in vitro by differentiated bovine granulosa cells and its production is FSH and not luteinizing hormone ( $\mathrm{LH}$ ) dependent (Klein et al., 1991). In addition we have found enhanced and prolonged effects of FSP upon luteinization in immature granulosa cells, whereas no significant effect of FSP could be observed on fully differentiated bovine granulosa cells (Shukovski et al., 1991). These observations led us to investigate the steady state concentrations of FSP mRNA in bovine follicles at different stages of development and in corpora lutea, to determine whether the FSP mRNA is expressed more abundantly at the onset of luteinization. 


\section{Materials and Methods}

\section{Tissue collection and preparation}

All tissues were collected at a local abattoir within $30 \mathrm{~min}$ of slaughter and maintained in an ice-cold mixture of Dulbecco's modified Eagle's medium and Ham's F12 (DMEM/F12; Flow Laboratory, NSW, Australia). Ovaries were transferred to the laboratory and dissected within $2 \mathrm{~h}$ of collection. Bovine follicles were dissected from the surrounding stroma and grouped according to diameter into five groups: $<3 \mathrm{~mm}(n=10$ follicles per pool and 14 follicles per pool), 4-6 mm $(n=6,10), 7-10 \mathrm{~mm}(n=6,8), 1115 \mathrm{~mm}(n=3,4)$ and $15.18 \mathrm{~mm}$ individual follicles. Follicles were cut in half and washed in fresh medium to avoid follicular fluid residue, and thereafter snap-frozen in liquid nitrogen. A pool of $7 \times 10^{7}$ granulosa cells was prepared from a large number of follicles of different sizes as previously described (Shukovski \& Findlay, 1990; Shukovski et al., 1990). After removing the granulosa cell layers, the theca interna was recovered by peeling it away from the internal surface of the follicle with forceps with the aid of a dissecting microscope. Corpora lutea were collected from cyclic cows and grouped into four stages designated according to Ireland et al. (1980): stage I-early; stage II-early-mid; stage III-mid-late; and stage IV-late (regressing). Corpora albicantia and corpus luteum of early pregnant cows were each pooled from three different animals. Liver tissue was collected from three cows and pooled before freezing.

\section{RNA isolation and northern blots}

Total RNA was isolated from frozen tissues by guanidine isothiocyanate extraction and $\mathrm{CsCl}$ centrifugation as described by Chirgwin et al. (1979), and the amount of RNA was estimated by measuring the optical density (OD). Aliquots of total RNA $(20 \mu \mathrm{g})$, except for pooled granulosa cells $(10 \mu \mathrm{g})$, were fractionated on $1 \cdot 2 \%$ agarose gels after denaturation with glyoxal and dimethylsulfoxide, and passively transferred to Hybond-N (Amersham Australia, Melbourne) nylon membranes by capillary blotting. The nylon membranes were baked at $80^{\circ} \mathrm{C}$ for $2 \mathrm{~h}$, UV-crosslinked for $10 \mathrm{~min}$ and prehybridized for $4-16 \mathrm{~h}$ in hybridization buffer $(50 \%$ formamide, $5 \times \mathrm{SSC}(1 \times \mathrm{SSC}$ is $0.15 \mathrm{~mol}$ sodium chloride $\mathrm{l}^{\prime}, 0.15 \mathrm{~mol}$ sodium citrate $1^{\prime}, \mathrm{pH} 7.4,50$ mmol sodium phosphate 1 ', $\mathrm{pH} 8.0$ ), $10 \times$ Denhardt's solution, $100 \mu \mathrm{g}$ herring sperm DNA ml ${ }^{1}$ ) at $42^{\circ} \mathrm{C}$. Membranes were hybridized for $18 \mathrm{~h}$ at $42^{\circ} \mathrm{C}$ with $1 \times 10^{6}$ c.p.m. denatured FSP cDNA fragment $\mathrm{ml}^{-1}$ solution (kindly provided by Biotech Australia Inc., NSW, Australia). The FSP cDNA probe was prepared by the random primer method of Feinberg \& Vogelstein (1983) to a specific activity of $1-3 \times 10^{9}$ c.p.m. $\mu \mathrm{g}{ }^{\prime} \mathrm{DNA}$ using [ $\left.\alpha{ }^{-32} \mathrm{P}\right] \mathrm{dCTP}$. Membranes were washed once for $20 \mathrm{~min}$ in $2 \times$ SSC plus $0.1 \%$ sodium dodecyl sulfate (SDS) and once in $0.2 \times$ SSC plus $0.1 \%$ SDS at room temperature followed by $0.1 \times$ SCC plus $0.1 \%$ SDS for 20 min at $60^{\circ} \mathrm{C}$. Autoradiography was performed with Kodak XAR-5 film and an intensifying screen at $-80^{\circ} \mathrm{C}$ for $8-12 \mathrm{~h}$. For rehybridization with a different probe, blots were boiled for $3 \mathrm{~min}$ in sterile, deionized distilled water and exposed to Kodak XAR film overnight to check that probes were completely removed. Blots were rehybridized with an $18 \mathrm{~S}$ probe at $65^{\circ} \mathrm{C}$ to assess the amount and integrity of total RNA loaded onto each gel.

The positions of 18 and 28S markers (Pharmacia, Uppsala, Sweden) on a separate lane on each gel and an RNA ladder (Bethesda Research Laboratories, Bethesda, MD, USA) for detection of molecular weight were stained with ethidium bromide.

\section{Probes}

The bovine FSP probe was a cDNA fragment isolated from a bovine granulosa cell cDNA library (Forage $e t$ al., 1986) and contained amino acids $11-189$ of the porcine sequence.

An oligonucleotide probe (30 mer) (Clements et al., 1988) for rat $18 \mathrm{~S}$ ribosomal RNA, which hybridized with cow and sheep ribosomal RNA, was end labelled (with $\tau-\left[{ }^{32} \mathrm{P}\right] \mathrm{ATP}(2000 \mathrm{Ci}$ mol ', Amersham Australia, Melbourne) to

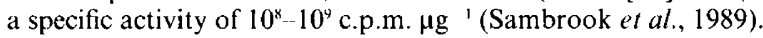

\section{Quantification of mRNA}

Messenger RNA concentrations on autoradiographs were quantified by densitometry (ISCO Model 1312 densitometer, Hewlett Packard integrator) for both FSP and 18S probes. The ratio between the FSP expression and the 18S expression was calculated for each of the samples and expressed as a percentage of the value for the largest follicle examined ( $18 \mathrm{~mm}$ in diameter).

\section{Statistical analysis}

Data from densitometric estimations of the abundance of FSP mRNA (corrected for loading) were subjected to analysis of variance followed by Duncan's multiple range $F$ test. Each data point represented the average of two 
values of each sample or pool derived from two different gels. The data for follicles were grouped as small $(<7 \mathrm{~mm}$; $n=3$ pools), medium ( $7-10 \mathrm{~mm} ; n=2$ pools) and large ( $>10 \mathrm{~mm} ; n=5$, made up of two pools and three individual follicles) for analysis.

\section{Results}

All ovarian tissues showed two hybridizing signals with the bovine FSP probe (Figs 1, 2 and 3 ). The stronger signal was detected at $2.8 \mathrm{~kb}$ and the weaker one at $1.8 \mathrm{~kb}$. The relationship between the expression of the 2.8 and $1.8 \mathrm{~kb}$ bands remained fairly constant. In samples with abundant message the $1.8 \mathrm{~kb}$ signal appeared as two close bands. However, the upper band of those two close bands was also observed in liver RNA which did not express the FSP message (Fig. 1), as well as in a ribosomal RNA sample which was included as a control (data not shown) and was regarded as nonspecific.

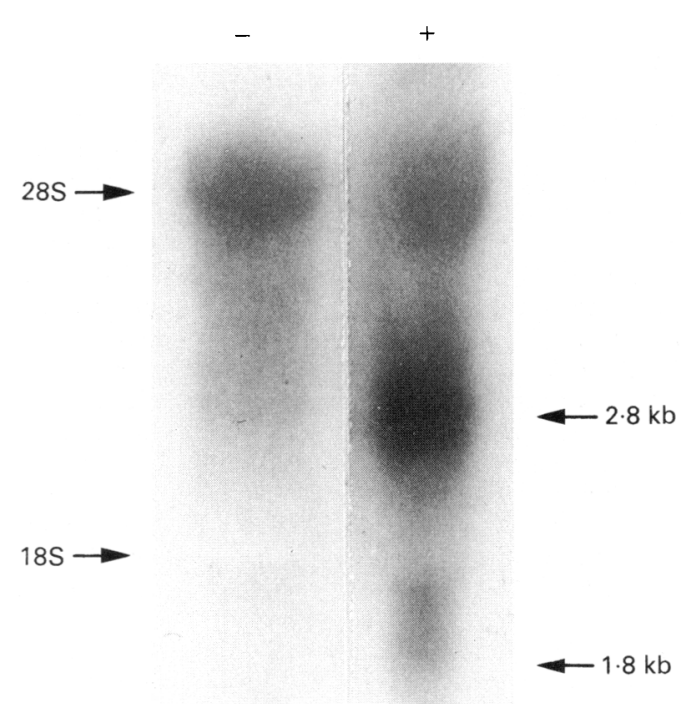

Fig. 1. Hybridization of ${ }^{32} \mathrm{P}$-labelled bovine FSP cDNA. $(-)$ bovine liver as negative control; (+) pooled bovine follicles as positive control $(20 \mu \mathrm{g}$ per lane). 2.8 and $1.8 \mathrm{~kb}$ indicate the sizes of FSP mRNA bands found in bovine follicles after northern blot analyses. 18 and $28 \mathrm{~S}$ ribosomal RNA markers are also shown.

FSP mRNA was detected in all bovine follicles examined with increasing abundance (relative to an $18 \mathrm{~mm}$ follicle) as folliculogenesis progressed (Fig. 2). Small follicles $(<3$ and $4-6 \mathrm{~mm}$ in diameter) showed the lowest relative abundance of mRNA which increased up to twofold as the follicles enlarged (Fig. 2). The strongest signal among the follicles was seen in large individual follicles ranging in size from 15 to $18 \mathrm{~mm}$, which is the size of the preovulatory follicle in cows. A significantly weaker signal was observed with RNA from the corpus luteum, with small but not significant differences between different stages in the luteal phase, the corpus albicans and corpus luteum from early pregnant animals (Fig. 3). Whole bovine ovary showed a similar degree of hybridization as the large follicles, whereas in the stroma the signal was significantly lower (Fig. 3). Samples from the theca showed a very faint but still detectable band (data not shown). The strongest hybridization signal, four times greater than the signal detected in an $18 \mathrm{~mm}$ follicle, was observed in RNA from a pool of granulosa cells isolated from follicles of various sizes (Fig. 2, lane 8). No hybridization was seen with RNA from bovine liver, which was used as a negative control 

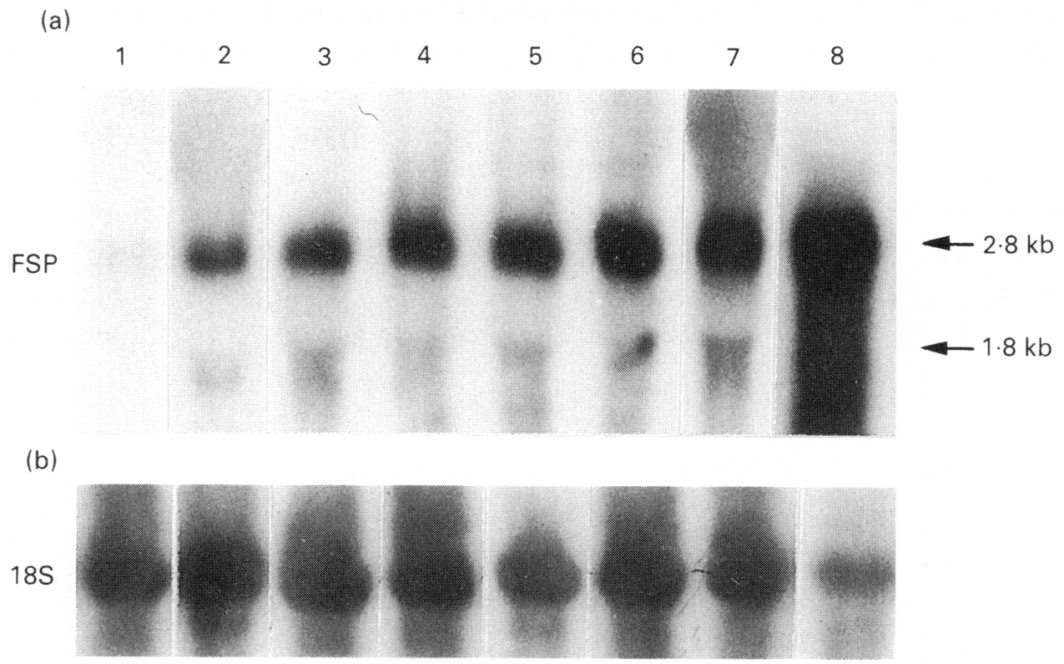

Fig. 2. Northern blot analyses of total RNA of bovine follicles ( $20 \mu \mathrm{g}$ per lane) and granulosa cells ( $10 \mu \mathrm{g}$ per lane) hybridized with ${ }^{32} \mathrm{P}$-labelled bovine FSP cDNA probe (a) and $18 \mathrm{~S}$ ribosomal RNA oligonucleotide probe (b). Pool of follicles $<3 \mathrm{~mm}$ in diameter (lane 1), 4-6 mm (lane 2), 7-10 mm (lane 3), 11-15 mm (lane 4), individual follicles of $15 \mathrm{~mm}$ (lane 5), $16 \mathrm{~mm}$ (lane 6), and $18 \mathrm{~mm}$ (lane 7) and isolated granulosa cells (lane 8). Each lane represents one of two pools, with similar results obtained with each pool hybridized on two different blots. Autoradiography was for $8-12 \mathrm{~h}$ for both the FSP and $18 \mathrm{~S}$ probes.

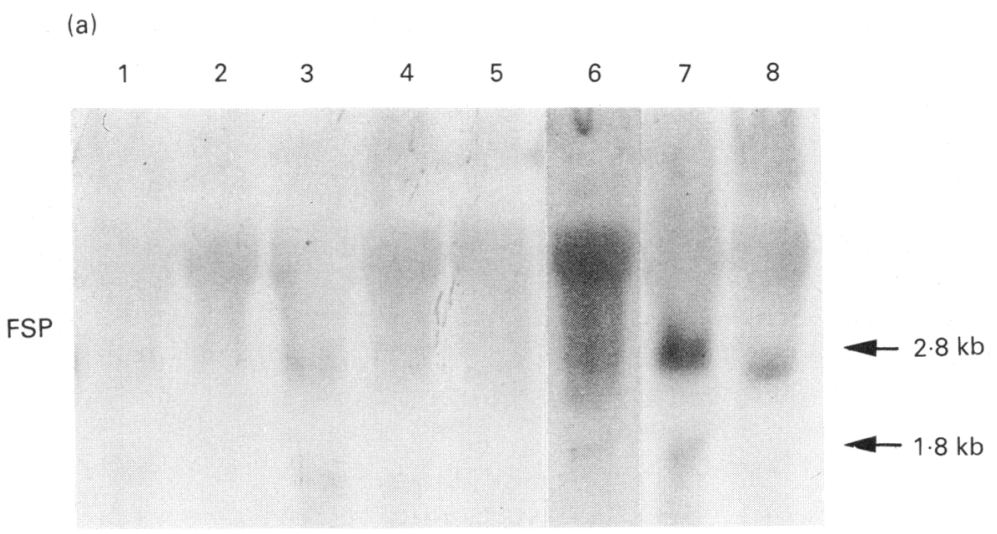

(b)

$18 \mathrm{~S}$

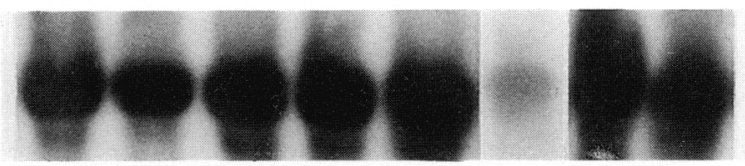

Fig. 3. Northern blot analyses of bovine corpora lutea from cyclic and pregnant animals, corpus albicans, ovary and stroma $\left(20 \mu \mathrm{g}\right.$ per lane) hybridized with ${ }^{32}$ P-labelled FSP cDNA probe (a) and $18 \mathrm{~S}$ ribosomal RNA oligonucleotide probe (b). Corpora lutea were from different stages of the luteal phase: early (lane 1), early-mid (lane 2), mid-late (lane 3) and late (lane 4); corpus albicans (lane 5); corpus luteum of pregnant animals (lane 6); ovary (lane 7) and stroma (lane 8). Autoradiography was for 8-12 h for both the FSP and $18 \mathrm{~S}$ probes. 
(Fig. 1). Amounts of bovine ovarian FSP expressed as mean densitometric units relative to $18 \mathrm{~mm}$ follicle as a control value (100\%) is shown (Fig. 4). Small follicles, including follicles less than $7 \mathrm{~mm}$ in diameter, demonstrated significantly lower amounts of FSP mRNA $(P<0.05)$ than large follicles (Fig. 4). Corpora lutea of all luteal stages, corpus luteum of pregnant cows and whole ovary also had significantly lower amounts of FSP mRNA than the large follicles. Since we analysed only one sample of corpus albicans and one sample of isolated granulosa cells, statistical analysis was not performed on these samples (Fig. 4). In all the samples hybridized with the bovine FSP probe, including the liver, a diffuse band was observed running at a similar position to 28S RNA. All blots were hybridized with an $18 \mathrm{~S}$ probe and showed a band at $1.4 \mathrm{~kb}$ for each of the samples.

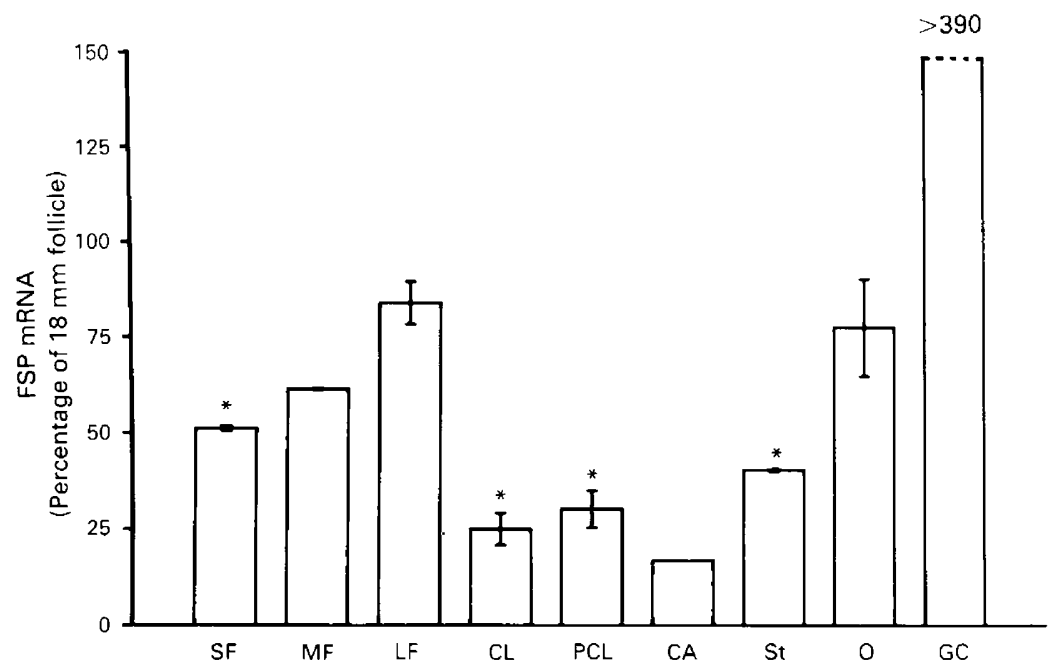

Fig. 4. Amounts of bovine ovarian FSP mRNA expressed as mean densitometric units \pm SEM $\%$ of control ( $18 \mathrm{~mm}$ follicle). Data are derived by densitometry of autoradiographs obtained following hybridization of ${ }^{32} \mathrm{P}$-labelled bovine FSP cDNA probe and oligonucleotide probe for $18 \mathrm{~S}$ ribosomal RNA to 20 or $10 \mu \mathrm{g}$ of total RNA, and calculated after correction for loading by comparison with 18S mRNA concentration. SF: small follicles $<7 \mathrm{~mm}(n=3)$; MF: medium follicles $7-10 \mathrm{~mm}(n=2)$; LF: large follicles $>10 \mathrm{~mm}(n=5)$; CL: corpora lutea $(n=4)$; PCL: CL from pregnant cows $(n=2)$; CA: corpus albicans $(n=1)$; St: ovarian stroma $(n=2)$; $\mathrm{O}$ : whole ovary $(n=3)$; GC: granulosa cells $(n=1) ;{ }^{*} P<0.05$ versus LF.

\section{Discussion}

The results show for the first time that FSP mRNA expression is present in the bovine ovary and consists of two bands, a major one at $2.8 \mathrm{~kb}$ and a minor one at $1.8 \mathrm{~kb}$. The existence of the larger band of FSP mRNA in ovarian tissue is consistent with reports of northern analyses of ovarian RNA in other species (Shimasaki et al., 1988a, b; 1989), whereas the minor band has been described only in total RNA from rat decidual tissue (Kaiser et al., 1990). The abundance of the minor band $(1.8 \mathrm{~kb})$ was related to the abundance of the major band $(2.8 \mathrm{~kb})$. In samples where the $2.8 \mathrm{~kb}$ signal was very low, for instance the corpus luteum, the second band could hardly be detected. In some cases where a strong signal was observed (large follicles, pool of granulosa cells), we could distinguish between two bands on the autoradiographs comprising the $1.8 \mathrm{~kb}$ form but it was impossible to determine their sizes accurately. Because the upper of these two close bands appeared in the liver and the ribosomal RNA samples, we regarded this band as a nonspecific signal. 
Likewise, the diffuse band hybridizing to the FSP probe in all samples at a position similar to ribosomal 28S was judged to be nonspecific, since it was also observed in the liver sample which showed no hybridization bands at 2.8 and $1.8 \mathrm{~kb}$ with the FSP probe.

In humans (Shimasaki et al., 1988b) pigs (Shimasaki et al., 1988a) and rats (Shimasaki et al., 1989), the $2 \cdot 4-2.6 \mathrm{~kb}$ band, previously reported as a $1.9 \mathrm{~kb}$ band (Esch et al., 1987), is thought to comprise two forms of mRNA which arise by alternative splicing but cannot be distinguished by northern analysis. We used $S_{1}$ nuclease assays with a specific probe to distinguish these two forms of FSP mRNA in rat ovary and other tissues (Michel et al., 1990). It is not known whether such an event occurs in the bovine ovary although it appears likely in view of the multiple forms of FSP (31, $35,39 \mathrm{kDa}$ ) that have been identified in bovine follicular fluid (Robertson et al., 1987) and a $45 \mathrm{kDa}$ FSP in medium conditioned by bovine granulosa cells (Klein et al., 1991). The two forms of mRNA that arise by alternate splicing would code for the 32 and $35 \mathrm{kDa}$ forms of FSP in humans, pigs and rats. If it is assumed that the 31 and $35 \mathrm{kDa}$ forms of bovine FSP arise in a similar way, this leaves the question of the origin of the 39 and $45 \mathrm{kDa}$ forms. The precursor protein sequences of the pig and human FSP predict one and two, respectively, potential $N$-linked glycosylation sites that could explain the higher molecular weight forms. No such sequence information exists for bovine FSP so it is not possible to predict the glycosylation sites. Alternatively, the larger molecular forms of bovine FSP would arise from other forms of alternate splicing or more than one FSP gene in cows. The absence of specific bands of FSP mRNA greater than $2.8 \mathrm{~kb}$ does not support this suggestion. The presence of a smaller band of FSP mRNA has been reported previously only in total RNA from rat decidua (Kaiser et al., 1990). The nature of this mRNA and the protein coded by it are not known.

Our observations revealed that the amount of FSP mRNA were relatively low in small antral follicles $(<7 \mathrm{~mm})$, and increased in the growing follicles to be most abundant in the preovulatory follicle $(>11 \mathrm{~mm})$. The strongest signal was detected when granulosa cells were isolated from follicles and hybridized with the FSP probe. However, a faint band was observed in RNA from theca tissue, most likely due to contamination with granulosa cells not removed during dissection. The stroma showed a weak band probably due to very small follicles $(<0.5 \mathrm{~mm})$ remaining in the ovary. In the transition from ovulatory follicle to a corpus luteum, the steady state levels of FSP mRNA decreased significantly showing only a slight hybridization during the entire luteal phase as well as in the corpus albicans and the corpus luteum of early pregnancy cows (Figs 2 and 3 ). This distribution of expression of FSP mRNA within the bovine ovary is consistent with in situ hybridization studies in rats (Shimasaki et al., 1989) and with the granulosa cell origin of FSP in bovine (Klein et al., 1991) and rat ovaries (U. Michel, J. W. McMaster and J. K. Findlay, unpublished observations).

We suggest that FSP promotes luteinization or atresia of follicles by a local mechanism (Findlay et al., 1990; Shukovski et al., 1991). Consequently we would expect to find more FSP in larger preovulatory or atretic follicles. The data on increasing steady state values of FSP mRNA as bovine follicles increase in size (and frequency of atresia) would support this view.

In preliminary experiments using different size follicles and corpora lutea from sheep ovaries, hybridization with the bovine FSP probe resulted in bands $(2.8$ and $1.8 \mathrm{~kb})$ of similar size to those seen with samples from cows. In contrast to the findings in cows, the signal was most profound in small follicles $(<4 \mathrm{~mm}$ in diameter), and showed higher abundance than in large follicles $(>6 \mathrm{~mm}$; day 16 of the cycle). Although the FSP mRNA measured in sheep follicles showed the opposite pattern to that found in cows, the large follicles were collected on day 16 and could represent ovulatory follicles that were already luteinizing and had decreased gene expression. Further studies with better timing of collection of the ovaries are therefore required in sheep to verify whether or not the situation is different from that seen in cows.

In summary we have demonstrated expression of two forms $(2.8$ and $1.8 \mathrm{~kb})$ of FSP mRNA in bovine ovarian tissue, with the major expression in granulosa cells. In cows, FSP mRNA expression increased as follicles grew, supporting the hypothesis that FSP has local actions 
regulating folliculogenesis and luteinization. In sheep ovaries the same size bands of FSP mRNA were expressed, but further studies are necessary to investigate the pattern of expression during the follicular phase of the cycle.

We thank F. de Jong and R. Forage from Biotech Australia Pty Ltd for their generous gift of the bovine FSP probe. This study was supported by the National Health and Medical Research Council of Australia.

\section{References}

Chirgwin, J.M., Przybylz, A.E., MacDonald, R.J. \& Rutter, W.J. (1979) Isolation of biologically active ribonucleic acid from sources enriched in ribonuclease. Biochemistry 18, 5294-5299.

Clements, J.A., Matheson, B.A., Wines, D.R., Brady, J.M., MacDonald, R.J. \& Funder J.W. (1988) Androgen dependence of specific kallikrein gene family members expressed in rat prostate. Journal of Biological Chemistry 263, $16132-16137$.

Esch, F., Shimasaki, S., Mercado, M., Cooksey, K., Ling, N., Ying, S.Y., Ueno, N. \& Guillemin, R. (1987) Structural characterization of follistatin: a novel follicle-simulating hormone release-inhibiting polypeptide from the gonad. Molecular Endocrinology $\mathbf{1}$, 849-855.

Feinberg, A.P. \& Vogelstein, B. (1983) A technique for radiolabeling DNA restriction endonuclease fragments to high specific activity. Analytical Biochemistry 132, $6 \cdots 13$.

Findlay, J.K., Xiao, S. \& Shukovski, L. (1990) Role of inhibin-related peptides as intragonadal regulators. Reproduction, Fertility and Development 2, 205-218.

Forage, R.G., Ring, J.M., Brown, R.W., Mclnerney, B.V., Cobon, G.S., Gregson, D.M., Robertson, D.M., Morgan, F.J., Hearn, M.T.W., Findlay, J.K., Wettenhall, R.E.H., Burger, H.G. \& de Kretser, D.M. (1986) Cloning and sequence analysis of cDNA species coding for the two subunits of inhibin from bovine follicular fluid. Proceedings of the National Academ.' of Sciences USA 83, 3091-3095.

Ireland, J.J., Murphee, R.L. \& Coulson, P.B. (1980) Accuracy of predicting stages of bovine estrous cycle by gross appearance of the corpus luteum. Journal of Dairy Science 63, 155-163.

Kaiser, M., Gibori, G. \& Mayo, K.E. (1990) The follistatin gene expressed in decidual tissue. Endocrinology 126, 2768-2770.

Klein, R., Robertson, D.M., Shukovski, L., Findlay, J.K. \& de Kretser, D.M. (1991) The radioimmunoassay of follicle-stimulating hormone (FSH)-suppressing protein (FSP): stimulation of bovine granulosa cell FSP secretion by FSH. Endocrinology 128, 1048-1056.

Michel, U., Albiston, A. \& Findlay, J.K. (1990) Rat follistatin: gonadal and extragonadal expression and evidence for alternative splicing. Biochemical and Biophysical Research Communications 173, 401-407.

Robertson, D.M., Klein, R., de Vos, F.L., McLachlan, R.I., Wettenhall, R.E., Hearn, M.T.W., Burger, H.G. \& de Kretser, D.M. (1987) The isolation of poly- peptides with FSH suppressing activity from bovine follicular fluid which are structurally different to inhibin. Biochemical and Biophysical Research Communications 147, 744-749.

Sambrook, J., Fritsch, E.F. \& Maniatis, T. (1989) Molecular Biology: A Laboratory Manual Vol. 2. (2nd edn) Cold Spring Harbor Laboratory Press, New York.

Shimasaki, S., Koga, M., Esch, F., Mercada, M., Cooksey, K., Koba, A. \& Ling, N. (1988a) Porcine follistatin gene structure supports two forms of mature follistatin produced by alternative splicing. Biochemical and Biophysical Research Communications 152, 717-723.

Shimasaki, S., Koga, M., Esch, F., Cooksey, K., Mercada, M., Koba, A., Ueno, N., Ying, S.Y., Ling, N. \& Guillemin, R. (1988b) Primary structure of the human follistatin precursor and its genomic organization. Proceedings of the National Academy of Sciences USA 85, 42184222.

Shimasaki, S., Koga, M., Buscaglia, M.L., Simmons, D.M., Bicsak, T.A. \& Ling, N. (1989) Follistatin gene expression in the ovary and extragonadal tissues. Molecular Endocrinology 3, 651-659.

Shukovski, L. \& Findlay, J.K. (1990) Activin-A inhibits oxytocin and progesterone production by preovulatory bovine granulosa cells in vitro. Endocrinology 126, 2222-2224.

Shukovski, L., Fortune, J.E. \& Findlay, J.K. (1990) Oxytocin and progesterone secretion by bovine granulosa cells of individual preovulatory follicles cultured in serum-free medium. Molecular and Cellular Endocrinology 69, 17-24.

Shukovski, L., Findlay, J.K. \& Robertson, D.M. (1991) The effect of follicle-stimulating hormonesuppressing protein or follistatin on luteinizing bovine granulosa cells in vitro and its antagonistic effect on the action of activin. Endocrinology 129, 33953402 .

Ueno, N., Ling, N., Ying, S.Y., Esch, F., Shimasaki, S. \& Guillemin, R. (1987) Isolation and partial characterization of follistatin, a novel $M_{\mathrm{f}} 35000$ monomeric protein which inhibits the release of follicle-stimulating hormone. Proceedings of the National Academy of Sciences USA 84, 8282-8286.

Ying, S.Y. (1988) Inhibins, activins, and follistatins: gonadal proteins modulating the secretion of folliclestimulating hormone. Endocrine Review's 9, 267-293.

Received 9 July 1991 